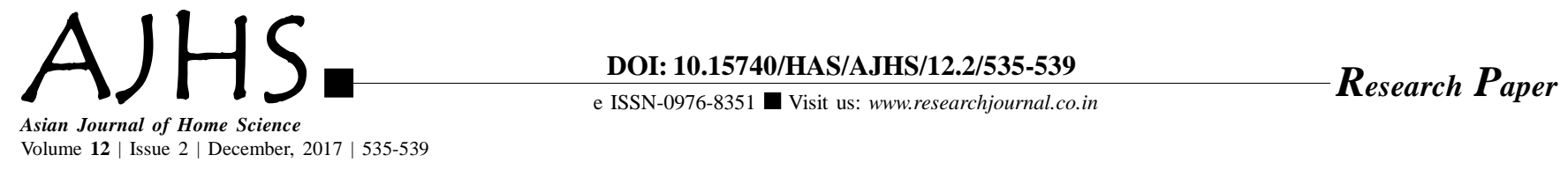

\title{
Drudgery perceived by the perishable goods sellers in West Garo Hills, Meghalaya
}

Received: 24.04.2017; Revised: 22.10.2017; Accepted: 07.11.2017

Author for Correspondence :

RANIMA SAIKIA

College of Home Science, Central

Agricultural University, TURA (MEGHALAYA) INDIA
ABSTRACT : The research was carried out to study the drudgery index of the various activities carried out by the perishable good sellers while doing the job of selling fish, poultry and mutton/pork. A total of 75 sellers were considered from three daily markets under Tura Municipal Board, West Garo Hills, Meghalaya. The findings show that among the fish sellers cutting of descaled fishes into pieces is the most drudgery prone activity.Cutting the dressed poultry into pieces and slaughtering of animals are the maximum drudgery prone activities among the poultry and mutton/pork sellers, respectively. Therefore, there is the need for such research studies which will further help the researchers who are dealing with designing of work stations and ergonomic tools to reduce the workload of the workers involved in drudgery prone activities.

GEY WORDS: Drudgery, Drudgery index, Time spent, Frequency score, Difficulty score

- HOW TO CITE THIS PAPER : Saikia, Ranima (2017). Drudgery perceived by the perishable goods sellers in West Garo Hills, Meghalaya. Asian J. Home Sci., 12 (2) : 535-539, DOI: 10.15740/HAS/AJHS/ 12.2/535-539. 